\title{
DIAGNOSTIK KESULITAN BELAJAR IPA SISWA SMPN KABUPATEN SUMENEP DENGAN ANALISIS DISKRIMINAN
}

\author{
Anik Anekawati, Habibi, Sayyida \\ Universitas Wiraraja Sumenep \\ e-mail : luk.luk10@yahoo.co.id
}

\begin{abstract}
ABSTRAK
Salah satu penyebab siswa gagal dalam mengikuti mata pelajaran IPA adalah guru sulit mendiagnosa jenis-jenis kesulitan siswa. Tujuan dari penelitian ini adalah : (1). Mengidentifikasi kesulitan belajar IPA siswa SMPN di Kabupaten Sumenep; (2). Mengembangkan model tes diagnostik kesulitan belajar mata pelajaran IPA pada siswa SMP yang efektif; (3). Menganalisis jenis kesulitan belajar yang berpengaruh terhadap ketuntasan belajar IPA pada siswa SMP; (4). Menganalisis jenis kesulitan belajar yang paling mampu membedakan antara kelompok siswa yang tuntas dengan kelompok siswa yang tidak tuntas belajar dengan menggunakan analisis diskriminan.

Variabel prediktor sebanyak 10 yaitu: mendefinisikan konsep, menginterpretasi data atau grafik, memahami hubungan spatial, memprediksi, mengontrol variabel, membuat hipotesis, menggunakan dan memanipulasi angka-angka, menyimpulkan, memilih alat eksperimen, melakukan eksperimen. Variabel Respon yaitu ketuntasan belajar IPA. Tahapan penelitian dilakukan didasarkan pada tujuan dan desain penelitian yaitu : (1). Mengidentifikasi kesulitan belajar IPA melalui FGD I; (2). Mendesain tes diagnostik melalui FGD II dengan materi tes adalah IPA terpadu (3). Mengimplementasikan tes diagnostik kesulitan belajar IPA; (4). Menganalisis hasil tes menggunakan analisis diskriminan.

Hasil penelitian ini adalah: (1). Hasil identifikasi kesulitan belajar yang sering terjadi pada siswa di Sumenep adalah kurang membaca, sulit memahami konsep, sulit menyimpulkan data percobaan, sulit membaca grafik, sulit menghafal istilah-istilah biologi; (2). Desain tes diagnostik kesulitan belajar dengan materi IPA Terpadu (integrative science) sebanyak 10 soal essay denga rentang nilai 0-10. Nilai 10 diberikan jika mampu menjawab benar disertai dengan alasan benar, hingga skor 0 jika tidak menjawab atau jawaban sama sekali salah. Bentuk tes mengadopsi model tes PISA (Programme for International Student Assessment) yang dikembangkan oleh OECD (Organization for Economic Operation and Development) tahun 2012; (3). Jenis Kesulitan yang mempengaruhi ketuntasan belajar adalah menginterpretasi data dan grafik, memahami hubungan spatial dan memilih alat eksperimen; (4). Jenis kesulitan belajar yang mampu membedakan kelompok siswa yang tuntas dan tidak tuntas belajar adalah memahami hubungan spatial dan memilih alat eksperimen. Dari 124 siswa yang tuntas belajar, terdapat 83 siswa sesuai prediksi dan 41 siswa masuk pada klasifikasi yang salah. Dari 189 siswa yang tidak tuntas belajar, terdapat 107 siswa sesuai prediksi dan 82 siswa masuk pada klasifikasi yang salah.
\end{abstract}

\section{Kata kunci : Tes Diagnostik, PISA, Analisis Diskriminan}

\section{PENDAHULUAN}

Banyak pelaku dan pemerhati pendidikan, baik itu siswa, guru atau orang tua mendapatkan hasil proses pembelajaran yang kurang memuaskan. Beberapa kegagalan tersebut dapat disebabkan beberapa hal, salah satunya terkait dengan kesulitan belajar. Kadangkala, guru kurang memahami jenis kesulitan belajar siswa atau tidak mempunyai alat uji kesulitan belajar yang tepat. Mata pelajaran IPA, sebagai contoh, yang mengajarkan fakta, konsep, dan prosedur ilmiah adalah salah satu mata pelajaran yang secara tradisonal dianggap sulit (Mariana, 2009) bagi siswa SMP, dan pada akhirnya prestasi belajarnya rendah. Mendiagnosis faktorfaktor yang menyebabkan kesulitan belajar siswa menjadi sangat penting sebab dapat menjadi acuan bagi guru dalam menentukan arah pembelajarannya 
(Depdiknas, 2004). Dengan demikian guru dapat mengambil keputusan dalam memberikan konsentrasi kebutuhan spesifik kepada siswa (Santrock, 2010) secara efektif dan efisien, baik saat kegiatan belajar reguler, kegiatan remidial serta penguatan (reinforcement).

Banyak pakar pendidikan yang mengklasifikasikan kesulitan-kesulitan belajar IPA, namun mereka dapat dikategorikan antara lain: 1) melakukan observasi; 2) melakukan klasifikasi; 3) menggunakan dan memanipulasi angkaangka; 4) berkomunikasi; 5) melakukan prediksi; 6) menarik kesimpulan; 7) mengontrol variabel; 8) menginterpretasikan data; 9) merumuskan hipotesis; dan 10) melakukan eksperimen. (Hakim, 2000).

1) Kesulitan belajar dalam melakukan observasi adalah kesulitan dalam menggunakan alat indra dengan baik dan cermat saat mengamati suatu obyek atau peristiwa, sehingga mereka harus melibatkan kemampuan pengamatan, ketekunan, ketelitian dan ketepatan dalam melakukan pengukuran.

2) Kesulitan belajar melakukan klasifikasi merupakan kesulitan mengidentifikasikan obyek atau peristiwa, menunjukkan kesamaankesamaan, perbedaan-perbedaan, dan hubungan antara satu dengan yang lain.

3) Kesulitan belajar menggunakan dan memanipulasi angka-angka merupakan kesulitan dalam menggunakan dan memanipulasi angka-angka, serta merupakan kemampuan proses yang fundamental dalam pelajaran IPA.

4) Kesulitan belajar berkomunikasi adalah kesulitan menyampaikan ide atau gagasan dengan jelas, tepat, dan tidak menimbulkan keragu-raguan. Kemampuan tersebut untuk menjelaskan sifat-sifat benda, perubahan sifat-sifat benda, membuat gambaran yang menunjukkan posisi relatif suatu ukuran benda, menjelaskan secara verbal hubungan dan kecenderungan yang tampak dalam sebuah grafik atau lainnya.

5) Kesulitan belajar melakukan prediksi merupakan kesulitan dalam memberikan pendapat khusus tentang kemungkinan hasil pengamatan yang akan datang atau yang belum dilakukan atau kemampuan melihat adanya konsekuensi serta perkiraan akan kejadian yang akan datang. Prediksi tersebut didasarkan pada hasil observasi, pengukuran, dan kesimpulan tentang hubungan antara variabel-variabel yang dimati. Prediksi yang cermat dihasilkan dari observasi yang luas dan teliti secara pengukuran yang tepat.

6) Kesulitan belajar menarik kesimpulan adalah kesulitan memberikan penjelasan terhadap hasil observasi. Suatu kesimpulan tersebut diuji dengan pengamatan, dan apabila suatu kesimpulan tersebut tidak ditunjang oleh data pengamatan maka perlu dibuat kesimpulan baru. Artinya, setiap observasi atau sekumpulan observasi dapat dibuat lebih dari satu kesimpulan. Dalam pelajaran IPA, siswa dituntut agar terampil dalam membuat satu atau lebih kesimpulan dari serangkaian observasi, mengidentifikasi observasi yang menunjang kesimpulan, menjelaskan dan mendemonstrasikan observasi lain yang dibutuhkan untuk menguji kesimpulan alternatif, serta mengidentifikasi kesimpulan yang harus diterima, ditolak, atau dimodifikasi yang didasarkan pada observasi.

7) Kesulitan belajar mengontrol variabel adalah kesulitan yang mencakup keterampilan-keterampilan antara lain: mengidentifikasi variabelvariabel eksperimen, mengidentifikasi variabel-variabel yang akan dibuat tetap atau dihilangkan/dinetralkan pengaruhnya dalam suatu eksperimen, mengidentifikasi variabel-variabel 
lainnya, seperti variabel moderator dan variabel penyela, membedakan antara kondisi yang dapat membuat netral pengaruh suatu variabel dengan kondisi yang dapat membuat variabel itu berpengaruh, menyusun suatu prosedur pengujian untuk melihat pengaruh variabel - variabel eksperimen terhadap variabel-variabel respon, dan mengidentifikasi variabel-variabel yang sangat sukar dikontrol dalam suatu penyelidikan atau eksperimen.

8) Kesulitan belajar menginterpretasi data merupakan kesulitan melakukan interpretasi untuk menuntun siswa ke arah penarikan kesimpulan, prediksi, dan perumusan hipotesis, dan interpretasi sehubungan dengan pengembangan keterampilan dalam menggunakan data statistik, seperti harga rata-rata median, varian, dan lain-lain.

9) Kesulitan belajar merumuskan hipotesis merupakan kesulitan menyusun generalisasi yang didasar-kan atas pengetahuan yang dimiliki dengan melihat hasil observasi yang telah dilakukan proses generalisasi.

10) Kesulitan belajar melakukan eksperimen merupakan kemampuan melakukan suatu proses yang mencakup semua keterampilan proses yang ada. Seseorang yang ingin melakukan eksperimen biasanya mulai dengan masalah dan observasi yang mewujudkan pertanyaanpertanyaan yang perlu dijawab. Untuk itu, dilakukanlah eksperimen, mulai dari yang paling sederhana sampai dengan eksperimen yang rumit melibatkan banyak variabel. Keterampilan ini meliputi: keterampilan mengidentifikasikan variabel-variabel yang akan dikontrol serta merumuskan definisi operasional variabel yang dilibatkan, keterampilan menyusun tes dan mengumpulkan data yang relevan dengan tes tersebut, dan keterampilan menyusun laporan eksperimen yang menyatakan seberapa jauh data yang dikumpulkan mendukung hipotesis yang telah dirumuskan.

Namun demikian, belum adanya model tes diagnosis yang baku menjadikan para guru belum memiliki panduan bagaimana menyusun tes diagnostik. Beberapa pakar penyusun tes hasil belajar baku nasional yang mengatakan bahwa tes buatannya dapat dipakai untuk tes diagnostik (Santrock, 2010: 207) agaknya perlu "dipikirkan," sebab agar dapat dipakai sebagai tes diagnostik harus memiliki spesifikasi dan syarat-syarat tertentu. Untuk itu perlu dikembangkan model tes diagnosis kesulitan belajar IPA bagi siswa SMP, sehingga diharapkan menjadi acuan bagi para guru dalam rangka meningkatkan kualitas hasil pembelajaannya. Tes diagnosis tersebut untuk mengeksplorasi kesulitan-kesulitan belajar IPA yang dialami siswa SMP. Kemudian apakah jenis kesulitan belajar hasil temuan mempengaruhi ketuntasan belajar siswa. Untuk mengetahui jenisjenis kesulitan yang mempengaruhi ketuntasan belajar diperlukan alat uji statitik yang dapat mengklasifikasikan siswa ke dalam kelompok tuntas belajar dan kelompok yang tidak tuntas belajar adalah analisis diskriminan.

Penelitian ini bertujuan: Mengembangkan model tes diagnostik kesulitan belajar mata pelajaran IPA pada siswa SMP yang efektif; (2) Menganalisis jenis kesulitan belajar yang berpengaruh terhadap ketuntasan belajar IPA pada siswa SMP; (3) Menganalisis jenis kesulitan belajar yang paling mampu membedakan antara kelompok siswa yang tuntas dengan kelompok siswa yang tidak tuntas belajar dengan menggunakan analisis diskriminan.

\section{METODE PENELITIAN}

Populasi dalam penelitian ini adalah seluruh siswa SMP Negeri Sumenep kelas VIII sejumlah 1142 siswa tersebar dalam 39 kelas. Teknik sampling 
yang digunakan adalah Metode Probability Sampling yaitu Metode Sampling Cluster yang bersifat accidental dimana cluster didasarkan pada kelas-kelas yang ada di SMP Negeri Sumenep kelas VIII. Jumlah sampel yang digunakan pada penelitian ini sebanyak 313 siswa dari 11 kelas, diringkas pada tabel 1.

Tabel 1. Jumlah dan Komposisi Sampel Penelitian

\begin{tabular}{lrr}
\hline Nama Sekolah & $\begin{array}{c}\text { Jumlah } \\
\text { Peserta } \\
\text { Tes }\end{array}$ & Prosentase \\
\hline SMPN 1 Kalianget & 68 & $21.7 \%$ \\
\hline SMPN 2 Sumenep & 115 & $36.7 \%$ \\
\hline SMPN 3 Sumenep & 46 & $14.7 \%$ \\
\hline SMPN 4 Sumenep & 24 & $7.7 \%$ \\
\hline SMPN 5 Sumenep & 45 & $14.4 \%$ \\
\hline SMPN 6 Sumenep & 15 & $4.8 \%$ \\
\hline Jumlah & $\mathbf{3 1 3}$ & $\mathbf{1 0 0 \%}$ \\
\hline
\end{tabular}

Variabel-variabel dalam penelitian ini adalah 10 variabel prediktor dengan skala data metrik dan satu variabel respon dengan skala data nonmetrik. Variabel prediktor merupakan jenis-jenis kesulitan belajar mata pelajaran IPA, yaitu: mendefinisikan konsep, menginterpretasi data atau grafik, memahami hubungan spatial, memprediksi, mengontrol variabel, membuat hipotesis, menggunakan dan memanipulasi angka-angka, menyimpulkan, memilih alat eksperimen, melakukan eksperimen. Variabel Respon yaitu ketuntasan belajar IPA.

Desain penelitian digambarkan pada gambar 1. Focus Discussion Group I bertujuan mengeksplorasi informasi terkait dengan kondisi siswa dan lingkungan belajar, sebagai dasar merancang tes diagnostik kesulitan belajar IPA. Eksplorasi ini dengan cara pengisian kuisioner dan tanya jawab. FGD II dilaksanakan untuk membuat rancangan soal tes diagnostik kesulitan belajar IPA untuk tingkat SMP beserta kisi-kisi. Tes hasil revisi diujikan ke siswa untuk mendapatkan nilai dengan rentang 0-10. Nilai 10 diberikan jika mampu menjawab benar disertai dengan alasan benar, hingga skor 0 jika tidak menjawab atau jawaban sama sekali salah. Nilai ini digunakan sebagai dasar mendiagnosa kesulitan belajar siswa.

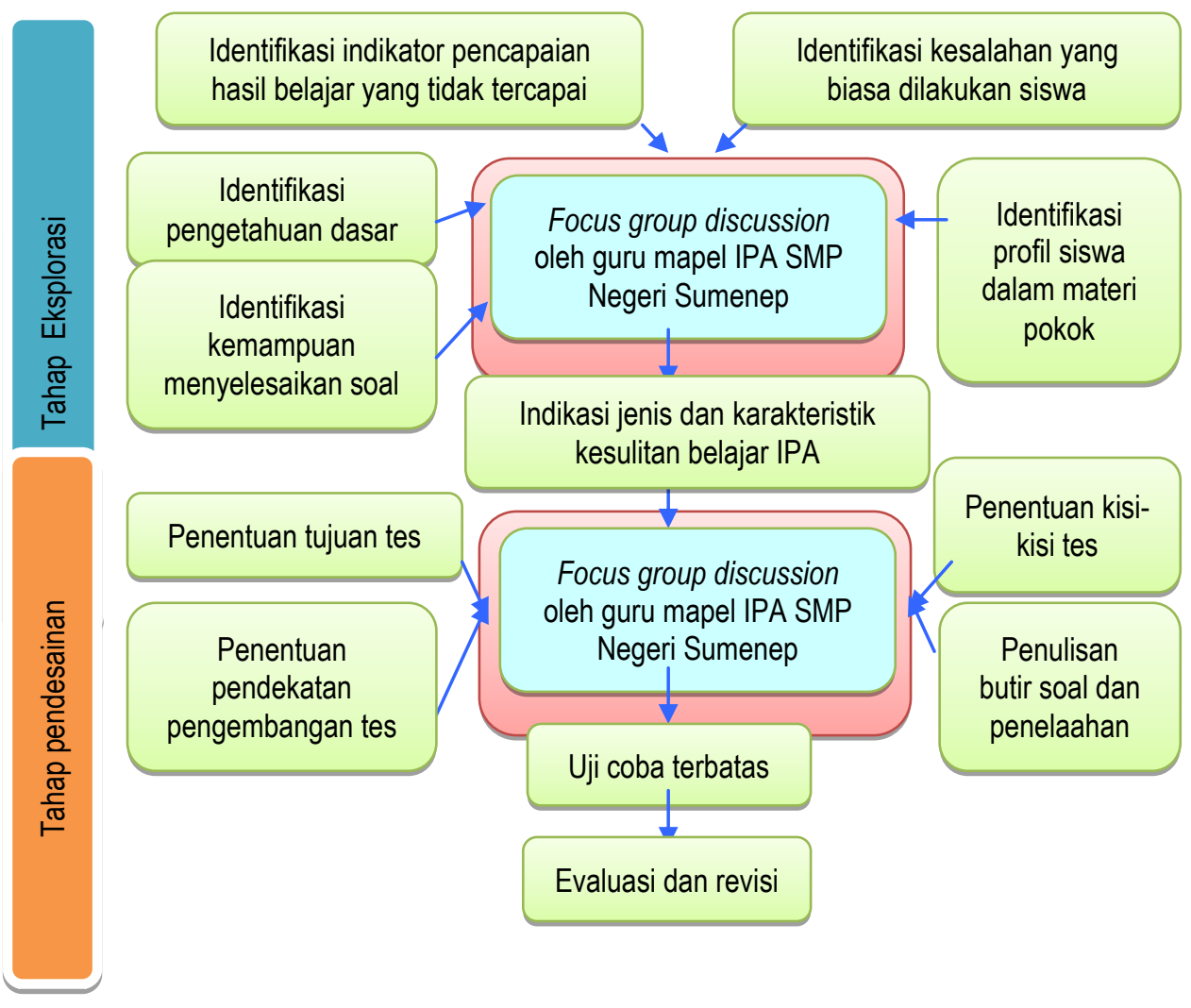




\section{Lanjutan :}
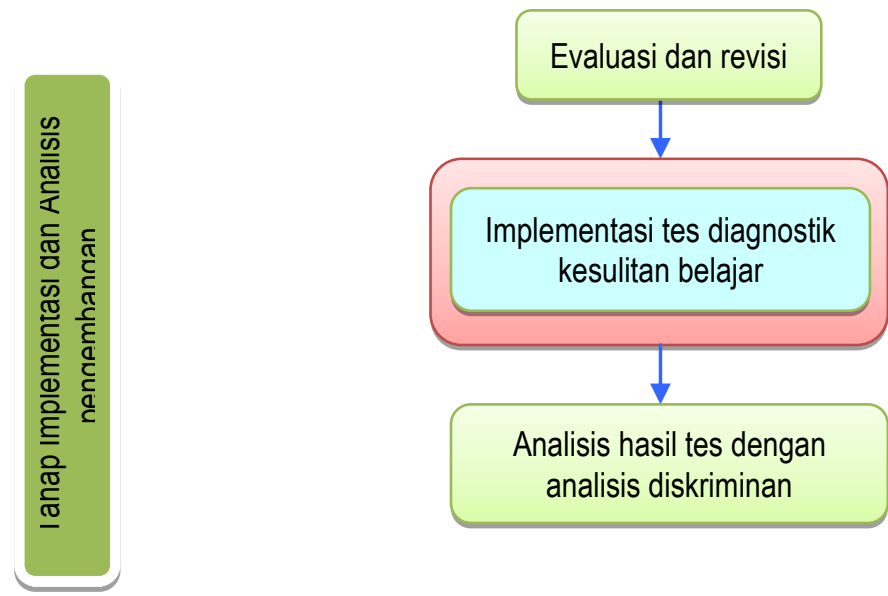

Gambar 1. Desain Penelitian

\section{HASIL DAN PEMBAHASAN \\ Hasil}

FGD I dilakukan dalam rangka mengeksplorasi informasi terkait dengan kondisi siswa dan lingkungan belajar, sebagai dasar merancang tes diagnostik kesulitan belajar IPA. Hasil identifikasi FGD I dirangkum pada tabel berikut :

Tabel 2. Hasil Identifikasi FGD I

\begin{tabular}{|c|c|c|}
\hline No & Uraian Identifikasi & Hasil Kuisioner \\
\hline 1 & $\begin{array}{l}\text { Rata-rata jumlah siswa per } \\
\text { kelas }\end{array}$ & 25 siswa \\
\hline 2 & Suasan belajar IPA & $\begin{array}{l}\text { Siswa malas berhitung, posisi duduk klasikal, dan siswa lebih senang } \\
\text { belajar di luar kelas (ekosistem) }\end{array}$ \\
\hline 3 & Identifikasi awal oleh guru & Jarang dilakukan karena keterbatasan waktu \\
\hline 4 & Kondisi intelengensi siswa & Sebagian besar sedang ke bawah \\
\hline 5 & Motivasi siswa belajar IPA & $\begin{array}{l}\text { Antusias belajar IPA jika disertai audio, kurang kosentrasi dan } \\
\text { kurang adanya motivasi dari orang tua }\end{array}$ \\
\hline 6 & $\begin{array}{l}\text { Latar belakang sosio } \\
\text { ekonomi siswa }\end{array}$ & Sebagian besar berlatar belakang ekonomi kurang mampu \\
\hline 7 & $\begin{array}{l}\text { Ketersediaan dan pemanfaat- } \\
\text { an laboratorium IPA }\end{array}$ & $\begin{array}{l}\text { Alat lab. kurang lengkap, KBM klasikal lebih didominasi } \\
\text { pembelajaran kelas }\end{array}$ \\
\hline 8 & $\begin{array}{l}\text { Jenis kesulitan belajar IPA } \\
\text { bagi siswa menurut guru IPA }\end{array}$ & $\begin{array}{l}\text { Kurang membaca, sulit memahami konsep, sulit menyimpulkan data } \\
\text { percobaan, sulit membaca grafik, sulit menghafal istilah biologi }\end{array}$ \\
\hline
\end{tabular}

Berdasarkan hasil identifikasi di FGD I ini sebagai landasan pembuatan tes diagnostik kesulitan belajar IPA, terutama pertanyaan nomor 8 . Dari hasil identifikasi bahwa kesulitan belajar yang sering terjadi pada siswa di Sumenep adalah kurang membaca, sulit memahami konsep, sulit menyimpulkan data percobaan, sulit membaca grafik, sulit menghafal istilah-istilah biologi.

FGD II menghasilkan tes terdiri dari 10 butir bertipe uraian (subyektif) di mana subyek memperoleh skor nilai dengan rentang 0-10. Nilai 10 diberikan jika mampu menjawab benar disertai dengan alasan benar, hingga skor 0 jika tidak menjawab atau jawaban sama sekali salah. Materi tes adalah IPA terpadu (integrative science), bentuk tes mengadopsi model tes PISA (Programme for International Student Assessment) yang dikembangkan oleh OECD (Organization for Economic Operation and Development) tahun 2012. Penggunaan model tes di atas dimaksudkan agar dapat lebih spesifik mendiagnosis jenis-jenis kesulit- 
an belajar IPA melalui pendekatan pengetahuan terstruktur untuk memecahkan masalah (Saintifik) serta arah pengembangan Kurikulum Matapelajaran IPA ke depan (bahan uji publik publik
Kurikulum 2013 Kemendikbud, 29 November 2012; Dokumen Kurikulum 2013 Kemendikbud, Desember 2012). Kisi-kisi tes diagnostik diringkas pada tabel berikut.

Tabel 3. Kisi-kisi (Desain) Tes Diagnos-tik Profil Siswa dalam Penguasaan Materi

\begin{tabular}{clc}
\hline Kode & \multicolumn{1}{c}{ Jenis Kompetensi } & Jumlah butir \\
\hline 01 & Memahami konsep & 1 \\
\hline 02 & Mengintepretasi data dan grafik & 1 \\
\hline 03 & Memahami hubungan spasial & 1 \\
\hline 04 & Memprediksi & 1 \\
\hline 05 & Mengontrol variabel & 1 \\
\hline 06 & Membuat hipotesis & 1 \\
\hline 07 & Menggunakan dan memanipulasi angka & 1 \\
\hline 08 & Menyimpulkan & 1 \\
\hline 09 & Memilih alat eksperimen & 1 \\
\hline 10 & Melakukan eksperimen & 10 \\
\hline
\end{tabular}

Hasil output pengujian terhadap jenis kesulitan belajar yang berpengaruh terhadap ketuntasan belajar diringkas pada tabel berikut :

Tabel 4. Ringkasan Hasil Uji Diskriminan

\begin{tabular}{llrl}
\hline No & \multicolumn{1}{c}{ Jenis Kesulitan } & Signifikansi & \multicolumn{1}{c}{ Kesimpulan } \\
\hline 1 & Memahami konsep & 0.512 & Tidak Berpengaruh \\
\hline 2 & Mengintepretasi data dan grafik & 0.032 & Berpengaruh \\
\hline 3 & Memahami hubungan spasial & 0.011 & Berpengaruh \\
\hline 4 & Memprediksi & 0.158 & Tidak Berpengaruh \\
\hline 5 & Mengontrol variabel & 0.418 & Tidak Berpengaruh \\
\hline 6 & Membuat hipotesis & 0.372 & Tidak Berpengaruh \\
\hline 7 & Menggunakan dan memanipulasi angka & 0.500 & Tidak Berpengaruh \\
\hline 8 & Menyimpulkan & 0.613 & Tidak Berpengaruh \\
\hline 9 & Memilih alat eksperimen & 0.001 & Berpengaruh \\
\hline 10 & Melakukan eksperimen & 0.310 & Tidak Berpengaruh \\
\hline
\end{tabular}

Dari tabel di atas tampak bahwa jenis kesulitan yang mempunyai nilai signifikansi kurang dari 0,05 adalah : menginterpretasi data dan grafik, memahami hubungan spatial dan memilih alat eksperimen. Hal ini dapat disimpulkan bahwa terdapat 3 jenis kesulitan belajar yang berpengaruh terhadap ketuntasan belajar yaitu: menginterpretasi data dan grafik, memahami hubungan spasial dan memilih alat eksperimen.

Hasil output pengujian terhadap jenis kesulitan belajar yang mampu membedakan kelompok tuntas dan tidak tuntas belajar diringkas pada tabel berikut:

Tabel 5. Ringkasan Hasil Uji Jenis Kesulitan Belajar yang Membedakan Ketuntasan

\begin{tabular}{cccc}
\hline No & Jenis Kesulitan & Signifikansi & \multicolumn{1}{c}{ Kesimpulan } \\
\cline { 1 - 3 } 1 & Memilih alat eksperimen & 0.001 & $\begin{array}{l}\text { Mampu membedakan kelompok siswa } \\
\text { tuntas dan tidak tuntas belajar }\end{array}$ \\
\cline { 1 - 2 } 2 & Memahami hubungan spasial & 0.000 & \\
\hline
\end{tabular}


Tabel di atas hanya menampilkan jenis kesulitan belajar yang mempunyai nilai signifikansi kurang dari 0,05 , yaitu: memahami hubungan spatial dan memilih alat eksperimen. Hal ini berarti terdapat 2 jenis kesulitan belajar IPA, yaitu memahami hubungan spatial dan memilih alat eksperimen yang mampu membedakan kelompok siswa yang tuntas belajar dan tidak tuntas belajar.

Hasil uji Wilks' Lambda diringkas pada tabel berikut :

Tabel 6. Ringkasan Hasil Uji Wilks' Lambda

\begin{tabular}{crrl}
\hline Wilks' Lambda & Chi-square & df & Sig. \\
\hline 0.943 & 18.227 & 2 & 0.000 \\
\hline
\end{tabular}

Dari tabel di atas tampak bahwa nilai signifikansi kurang dari 0,05 yang menunjukkan adanya perbedaan yang sangat jelas antara kelompok siswa yang tuntas dan tidak tuntas belajar IPA.

Tabel berikut menampilkan output koefisien fungsi diskriminan kanonik.

Tabel 7. Ringkasan Hasil Output Koefisien Fungsi Diskriminan Kanonik

\begin{tabular}{lr}
\hline \multicolumn{1}{c}{ Variabel } & \multicolumn{1}{c}{ Koefisien } \\
\hline Memahami Hubungan Spatial & 0.299 \\
\hline Memilih Alat Eksperimen & 0.424 \\
\hline (Constant) & -2.038 \\
\hline
\end{tabular}

Dari tabel di atas dapat dibuat fungsi diskriminan yaitu :

$$
\begin{aligned}
Z_{\text {score }} & =-2,038+0,299 \text { Hubungan Spatial } \\
& +0,424 \text { Memilih Alat Eksperimen }
\end{aligned}
$$

Fungsi diskriminan ini dapat digunakan untuk memprediksi siswa masuk kelompok ketuntasan belajar tertentu berdasarkan nilai memahami hubungan spatial dan nilai memilih alat eksperimen dari tes diagnostik yang dibuat pada penelitian ini.

Tabel berikut merupakan ringkasan output dari uji kesalahan klasifikasi.

Tabel 8. Ringkasan Hasil Kesalahan Klasifikasi

\begin{tabular}{llrrr}
\hline \multirow{2}{*}{ Data } & \multicolumn{2}{c}{ Hasil prediksi } & \\
\cline { 2 - 4 } & & Tuntas & $\begin{array}{r}\text { Tidak } \\
\text { Tuntas }\end{array}$ & Jml \\
\hline \multirow{2}{*}{ Data Asal } & Tuntas & 83 & 41 & 124 \\
\cline { 2 - 5 } & $\begin{array}{l}\text { Tidak } \\
\text { Tuntas }\end{array}$ & 82 & 107 & 189 \\
\hline Jumlah & & 165 & 148 & 313 \\
\hline
\end{tabular}

Dari tabel di atas dapat dijelaskan bahwa terdapat 124 siswa yang tuntas belajar, tetapi dari hasil analisis terdapat 83 siswa sesuai prediksi dan 41 siswa masuk pada klaisfikasi yang salah, seharusnya masuk pada kelompok siswa tidak tuntas. Terdapat 189 siswa yang tidak tuntas belajar, tetapi dari hasil analisis terdapat 107 siswa yang tidak tuntas dan 82 siswa yang salah klasifikasi dimana seharusnya masuk kelompok siswa yang tuntas belajar. Dari hasil perhitungan di atas dapat dicari ketepatan prediksi model adalah:

$$
(83+107) / 313 \times 100 \%=60,7 \%
$$

Sehingga dapat disimpulkan bahwa model di atas mempunyai ketepatan yang cukup tinggi, karena di atas $50 \%$.

Ringkasan jumlah kesalahan klasifikasi kelompok siswa tuntas dan tidak tuntas belajar IPA untuk masing-

\begin{tabular}{|c|c|c|c|c|}
\hline \multirow[b]{2}{*}{ Asal Sekolah } & \multicolumn{2}{|c|}{ Jumlah Kesalahan Klasifikasi } & \multirow[b]{2}{*}{$\begin{array}{c}\text { Total } \\
\text { Kesalahan } \\
\text { Klasifikasi }\end{array}$} & \multirow[b]{2}{*}{$\begin{array}{l}\text { Persentase } \\
\text { Kesalahan } \\
\text { Klasifikas }\end{array}$} \\
\hline & $\begin{array}{c}\text { Tidak Tuntas } \\
\text { Masuk Kelompok } \\
\text { Tuntas }\end{array}$ & $\begin{array}{c}\text { Tuntas Masuk } \\
\text { Kelompok Tidak } \\
\text { Tuntas }\end{array}$ & & \\
\hline SMPN 1 Kalianget & 12 & 9 & 21 & $30,88 \%$ \\
\hline SMPN 2 Sumenep & 11 & 31 & 42 & $36,52 \%$ \\
\hline SMPN 3 Sumenep & 6 & 19 & 25 & 54,355 \\
\hline
\end{tabular}
masing sekolah adalah sebagai berikut:

Tabel 9. Ringkasan Hasil Kesalahan Klasifikasi Masing-masing Sekolah 


\begin{tabular}{|c|c|c|c|c|}
\hline \multirow[b]{2}{*}{ Asal Sekolah } & \multicolumn{2}{|c|}{ Jumlah Kesalahan Klasifikasi } & \multirow[b]{2}{*}{$\begin{array}{c}\text { Total } \\
\text { Kesalahan } \\
\text { Klasifikasi }\end{array}$} & \multirow[b]{2}{*}{$\begin{array}{l}\text { Persentase } \\
\text { Kesalahan } \\
\text { Klasifikasi }\end{array}$} \\
\hline & $\begin{array}{c}\text { Tidak Tuntas } \\
\text { Masuk Kelompok } \\
\text { Tuntas }\end{array}$ & $\begin{array}{c}\text { Tuntas Masuk } \\
\text { Kelompok Tidak } \\
\text { Tuntas }\end{array}$ & & \\
\hline SMPN 4 Sumenep & 4 & 7 & 11 & $45,83 \%$ \\
\hline SMPN 5 Sumenep & 5 & 13 & 18 & $40 \%$ \\
\hline SMPN 6 Sumenep & 3 & 4 & 7 & $46,67 \%$ \\
\hline
\end{tabular}

Dari tabel di atas dapat disimpulkan bahwa sekolah SMPN 1 Kalianget mempunyai kesalahan klasifikasi yang paling rendah. Artinya, siswa SMPN 1 Kalianget yang masuk kelompok siswa tuntas belajar mampu menyelesaikan tes diagnostik lebih baik dibanding siswa pada kelompok tidak tuntas belajar. SMPN 6 Sumenep mempunyai kesalahan klasifikasi yang paling tinggi. Artinya, siswa SMPN 6 Sumenep baik yang masuk kelompok siswa tuntas belajar maupun kelompok tidak tuntas belajar mempunyai kemampuan menyelesaikan tes diagnostik yang hampir sama.

\section{Pembahasan}

Secara umum, kesulitan siswa dalam belajar IPA terletak pada aspek: (1) menginterpretasi data dan grafik; (2) memahami hubungan spasial; dan (3) memilih alat eksperimen. Kelemahan siswa dalam mengintepratasi data diindikasikan bahwa selama ini sains di sekolah banyak disajikan sebagai sebuah pengetahuan yang readiness atau siap pakai (diperoleh dari buku ajar atau guru) yang teacher centered daripada membangun kemampuan diri peserta didik dalam berpikir sebagaimana pendekatan konstruktivis. Hal ini menyebabkan siswa berpikir sangat dangkal, hanya mempelajari kulit luar suatu masalah, serta tidak memperluas pemikiran yang mendalam (Brooks dalam Santrock, 2010).

Selain itu, pola pembelajaran dan materi pelajaran IPA (Sains) yang ajarkan guru cenderung menekankan pada kumpulan fakta-fakta atau pengetahuan sains yang terpisah-pisah daripada mengajarkan sebuah konsep sains yang utuh, dan hal inilah merupakan permasalahan utama kesulitan siswa dalam belajar IPA. Sebuah konsep adalah elemen kognisi yang membantu menyederhanakan dan meringkas sebuah informasi (Medin, 2000). Jika pembelajaran sains menekankan pada penguasaan konsep sains, maka siswa akan mampu menggeneralisasi sebuah informasi atau fakta, sehingga lebih efisien dalam mengingat, merumuskan masalah, merumuskan hipotesis, memilih dan menggunakan peralatan yang tepat, memecahkan masalah, mengomunikasi (Santrock, 2010) fakta sains.

Fakta bahwa siswa lemah dalam mengidentifikasi hubungan sebab akibat (spasial) mengindikasikan bahwa siswa lemah dalam bernalar ilmiah (Frye, 1995 dalam Santrock, 2010), baik secara deduktif maupun induktif. Akibat pembelajaran teacher centered, siswa kurang diberi kesempatan guru untuk menggunakan daya nalarnya sendiri, mendasain sendiri percobaannya, dan menemukan alternatif-alternatif jawaban (Sanrock, 2010). Pembelajaran melatih kebebasan bernalar adalah penting dalam rangka mengambil kesimpulan (membentuk konsep) berdasarkan sebuah fakta (observasi) (Santrock, 2010), meskipun tidak sepenuhnya konklusif, tetapi akan meningkatkan kemampuan sains siswa (Santrock, 2010).

Sebagaimana dipaparkan di atas, meskipun semua sekolah obyek memiliki peralatan laboratorium memadahi, guru dalam pembelajarannya cenderung memilih pendekatan klasikal (ceramah), daripada membimbing siswa berkeahlian sains. Sains adalah berkenaan dengan melakukan pengamatan, mengukur, menganalisis data, dan memecahkan masalah yang senantiasa menggunakan 
alat eksperimen yang tepat. Guru sering menyajikan kegiatan demonstasi sains di laboratorium, namun dalam rangka mengikuti buku paket daripada strategi demonstrasi interaktif yang mengedepankan mengatasi miskonsepsi sains siswa (Sokoloff, 1997 dalam Santrock, 2010). Hal ini dilakukan guru sebab mereka menganggap lebih efisien dan tidak membuang waktu hanya untuk mengajar kebenaran secara imitatif (Santrock, 2010). Selain berakibat kemampuan daya sains siswa yang dangkal, siswa kesulitan dalam memilih (dan menggunakan) alatalat sains dalam memecahkan masalah.

Berdasarkan paparan di atas, dalam pembelajaran IPA (Sains) guru hendaknya mengedepankan membangun kemampuan peserta didik dalam: bernalar dan berpikir, mengembangkan rasa ingin tahu serta berorientasi aplikatif bidang IPA (Saintifik), terutama lebih menekankan pada aspek kemampuan sains yaitu: (1) menginterpretasi data dan grafik; (2) memahami hubungan spasial; dan (3) memilih alat eksperimen. Pendekatan yang dilakukan guru menggunakan konstruktivis, yaitu pembelajaran yang secara aktif mendorong peserta didik untuk menyusun dan membangun (to cunstruct) pengetahuan dan pemahaman (Santrock, 2010) sains dalam dirinya melalui kegiatan menemukan pengetahuan, merenung, dan berpikir kritis (Brooks dan Brooks, 2001, Santrock, 2010) melalui kegiatan penemuan dan investigasi laboratorium/menyelesaian permasalahan sehari-hari dalam konteks dunia peserta didik.

Fakta yang menunjukkan Siswa SMPN 1 Kalianget mempunyai kesalahan dalam klasifikasi yang paling rendah, sementara siswa SMPN 6 Sumenep mempunyai kesalahan dalam klasifikasi yang paling tinggi merupakan sesuatu yang unik. Secara geografis, SMPN 1 Kalianget adalah sekolah yang berada di daerah pinggiran kota (berjarak sekitar 7 kilometer dari pusat pemerintahan kabupaten Sumenep), dan merupakan pilihan utama para siswa (calon siswa) di wilayah Kecamatan Kalianget, sementara SMPN 6 Sumenep adalah pilihan terakhir bagi siswa (calon siswa) di wilayah kecamatan Kota Sumenep. Berdasarkan data sekolah, rasio jumlah calon siswa yang diterima dan jumlah SMPN 1 Kalianget menunjukkan paling tinggi dibandingkan sekolah lain (66\%), sementara SMPN 6 Sumenep jumlah pendaftar jauh lebih kecil dibandingkan jumlah pagu siswa yang diterima. Artinya, kualitas input (siswa dan calon siswa) SMPN 1 Kalianget lebih baik dibandingkan dengan sekolah lain. Selain itu, SMPN 1 Kalianget adalah salah satu sekolah yang ditunjuk pemerintah sebagai sekolah pelaksana Kurikulum 2013 yang berbasis Saintifik (Permendikbud RI nomor 70 tahun 2013). Dengan demikian, mereka telah terbiasa belajar IPA terpadu menggunakan pendekatan saintifik.

Fakta hasil kesalahan klasifikasi antara siswa kategori tuntas dalam mata pelajaran IPA di kelasnya, namun menjadi tidak tuntas dalam kategori tes diagnostik menjadi fenomena menarik. Dari data yang menujukkan pertingkat tertinggi jumlah kesalahan klasifikasi secara berturut-turut siswa: SMPN 3 Sumenep $(54,355 \%)$; SMPN 6 Sumenep $(46,67 \%)$, dan SMPN 4 Sumenep $(45,83 \%)$, di mana mereka merupakan sekolah berkategori bukan favorit dan memiliki kualitas input (siswa dan calon siswa) relatif paling rendah. Perlu dilakukan penelitian lanjutan untuk mengaji fenomena tersebut, sehingga dapat diketahui penyebab dan tindakan alternatif nya.

\section{KESIMPULAN}

1. Desain tes diagnostik Hasil FGD II dengan materi tes adalah IPA terpadu (integrative science) sebanyak 10 soal, bentuk tes mengadopsi model tes PISA (Programme for International Student Assessment) yang dikembangkan oleh OECD (Organization for Economic 
Operation and Development) tahun 2012.

2. Jenis Kesulitan yang mempengaruhi ketuntasan belajar adalah menginterpretasi data dan grafik, memahami hubungan spatial dan memilih alat eksperimen.

3. Dari hasil analisis diskriminan, jenis kesulitan belajar yang mampu membedakan kelompok siswa yang tuntas dan tidak tuntas belajar adalah memahami hubungan spatial dan memilih alat eksperimen.

\section{DAFTAR PUSTAKA}

Depdiknas. 2003. Pedoman Pengembangan Tes Diagnostik Sains SMP. Departemen Pendidikan Nasional: Direktorat Pendidikan Lanjutan.

Gudono. 2011. Analisis Data Multivariat. BPFE. Yogyakarta.

Hakim, Thursan. 2000. Belajar Secara Efektif. Puspa Swara. Jakarta.

Hidayati, Fajar. 2010. Kajian Kesulitan Belajar Siswa Kelas VII SMP Negeri 16 Yogyakarta Dalam Mempelajari Aljabar. (Skripsi tidak untuk dipublikasikan). Program Gelar Sarjana Universitas Negeri Yogyakarta. Yogyakarta.

Hudgins, Bryce, etc. 1982. Educational Psychology. FE Peacock Publisher, Inc. Illinois

Mariana, I Made Alit. 2009. Hakekat IPA dan Pendidikan IPA untuk Guru SD. PPPPTK IPA. Bandung.

Medin, D.L., 2000. Concepts: An overview dalam Encyclopedia $O f$ Psychology. Washington DC and New York: American Psychological and Oxford University Press.

Muhibbin, Syah. 2000. Psikologi Pendidikan dengan Suatu Pendekatan Baru. PT. Remaja Rosdakarya. Bandung.
Santrock, John. 2010. Psikologi Pendidikan, edisi dua. PMG. Jakarta

Wahyuningsih, Amalia S. 2004. Hubunan Antara Keceerdasan Emosional dengan Prestasi Belajar pada Siswa Kelas II SMU LAB School Jakarta Timur. Skripsi Fakultas Psikologi Universitas Persada Indonesia Y.A.I. Jakarta.

Widarjono, Agus. 2010. Analisis Statistika Multivariat Terapan. UPP STIM YKPN. Yogyakarta.

Winkel, WS (1997). Psikologi Pendidikan dan Evaluasi Belajar. Gramedia. Jakarta. 